\title{
The role of state support for small and medium-sized businesses in the context of innovative economic development
}

\author{
Viktoriya Kookueva ${ }^{1}$, and Juliya Tsertseil $^{1}$ \\ ${ }^{1}$ Plekhanov Russian University of Economics, Department of financial management, 117997, Moscow, Russia
}

\begin{abstract}
The problems of supporting small and medium-sized businesses are relevant for both developed and emerging economies. The level of business development depends on the effectiveness of state policy, which affects the rate of economic growth, GDP dynamics, and innovation activity. The article emphasizes the positive impact of strategic planning at the state level, the inclusion of projects for the development of small and medium-sized businesses in Federal and national projects, state programs. However, the article highlights the problems of increasing the effectiveness of state support. The author analyzes the directions of state support for small businesses, as well as support for individual sectors and sectors of the economy, such as energy. The growth of public investment in the construction of state property objects is emphasized. The development of the transport system, energy, construction of major facilities, and innovative development require state support. A comparative analysis of the forms and directions of support in Russia and other countries is provided. There is a need for state support tools that exclude simple spending of budget funds, and there is a need for clearer conditionality of receiving funds and reporting. For innovative development of economy it is necessary to provide such support tools that would increase the level of innovative activity, effectiveness of $\mathrm{R} \& \mathrm{~d}$, commercialization of intellectual property, the development of technological innovation.
\end{abstract}

\section{Introduction}

State programs are considered an important tool of the state in the purposeful development of priority areas of economic development. The idea of their creation was reduced to the need for strategic planning of activities aimed at developing priority areas of state policy. The implementation of many state programs begins in 2011, while their number has been increasing, some have been extended, and others have gradually moved into projects. The programs replaced or supplemented the Federal targeted programs that later became part of the programs. It should also be noted that in addition to state programs, there was a principle of project financing. Certain areas of state policy are now being implemented both through programs and through priority projects, Federal projects, and pilot projects. The problems of implementing state programs, the system of their financing, and the effectiveness of their implementation show the urgency of the problem of financial support for the development of the country's economy. An important area of innovative development of the country is the support and development of small and medium-sized businesses.

According to The "strategy of innovative development of Russia until 2020", the share of innovative products in the total output should be 25 $35 \%$, which also implies assistance to the development of small and medium-sized businesses.
According to the law on the development of small and medium-sized businesses in the country, infrastructure objects in the field of support for small and medium-sized businesses are additionally allocated: regional guarantee organizations, and such infrastructure objects as the credit assistance Fund (guarantee funds, guarantee funds) are excluded. A separate area of state support is allocated to:

* financing of research and development work at the expense of the budgets of the constituent entities of the Russian Federation;

* promotion of interregional cooperation between small and medium-sized businesses.

Within the framework of the " Forecast of long-term socio-economic development of the Russian Federation for the period up to 2030, the regional nature of the activities of small and medium-sized enterprises is highlighted, that is, they are linked to a specific territory. Target indicators for the implementation of the Forecast in the sphere of small and medium-sized businesses are:

* increasing the proportion of employees employed in small businesses to $32.2 \%$;

- the number of small and medium-sized enterprises per 1 thousand people will be 15.7 PCs. (excluding sole proprietors);

- the number of sole proprietors per 1 thousand people will be 38.2 PCs.

The growth in the number of small and mediumsized enterprises is expected as a result of the creation of 
innovative infrastructure, in particular technical and implementation special economic zones.

One of the directions of the state program "Economic development of Russia and innovative economy" is subprogram 2 "development of small and medium-sized businesses", which aims to increase their number and new jobs. The main support tools include: subsidizing interest rates on loans, leasing, targeted grants for business creation, repayment of the initial payment on leasing, microloans, creation of business infrastructure, and other types.

Decree No. 204 "on national goals and strategic objectives for the development of the Russian Federation for the period up to 2024" provides for the implementation of the national project "Small and medium-sized enterprises and support for individual entrepreneurial initiative", which implies promoting the development of innovative SMEs (small and medium sized enterprises-hereinafter referred to as SMEs) through grants, including $\mathrm{R} \& \mathrm{~d}$.

The European development strategy also pays attention to small and medium-sized businesses in the development of employment and prosperity of territories. They believe that SMEs will contribute to the strengthening of Europe, and the business environment will contribute to the development of a knowledge-based economy.

According to the report of the Commission on economic policy of Europe, SMEs make up $99.8 \%$ of the total number, which employs $2 / 3$ of the population, and produce $1 / 2$ of the added value. However, SMEs in Europe are still experiencing difficulties due to low competitiveness and lack of financial and human resources.

A lot of economic literature is devoted to improving the mechanism of state support for SMEs at the Federal and regional levels in Russia and abroad. The works of such Russian economists as A. N. Asaul, D. A. Gordeev, S. G. Tyaglov, I. V. Gorsky, B. G. Panskov, D. G. Chernik, A. Z. Dadashev, L. P. Pavlov, V. M. Pushkarev, M. V. Romanovsky, L. I. Goncharenko, M. R. Pinskaya, N. I. Malis, E. B. Shuvalov, T. N. Kostyuchenko, S. V. Levushkin, E. A. Nemkin, L. A. Vatutina, A. I. Smetanina, E. A. Bragina, others. Thus, V. V. Karpov, A. A. Korableva, and A. A. Mozzherina believe that in order to improve support for SMEs, it is necessary to improve methods for ensuring effective distribution of state resources and shifting the time of competitive selection [1].

A lot of research is devoted to a program-oriented approach to supporting entrepreneurship and developing an innovative economy. According to I. A. Bachurinskaya, the advantages of the program-target method include: the possibility of using different sources, the indicators measured by targets; the disadvantages: competition between territorial and sectoral approaches; problems of interdepartmental relations, inconsistencies, formalism, low performance discipline, weak orientation to innovative development. [2]

Mishchenko V. V. and Rezinkin A. Yu. note the constant changes in the priority directions of state development, changes in the number of programs, funding volumes, but they believe that they are objective in nature, associate them with the situation on world markets, the macroeconomic situation within the country, and the change in priorities. [3] Sadovnikova N. A., Klochkova E. N. suggested the use of expert assessment methods, preparation of reports on the implementation of the program, which has already been implemented in practice [4].

There is little research on the development of SMEs in developing countries. Thus, the study by Maryam Imam Ibrahim and Bintu Mustapha [5] revealed a positive relationship between state support and entrepreneurial orientation and modern marketing. The importance of the SME segment in the development of the national economy is noted in both developed and developing countries [6].

It is noted that subsidizing exporters has a positive effect on improving the competitiveness of SMEs [7]

The problems of SMEs are not their number, but their quality characteristics, such as a small number of exporters, technology start-UPS, and innovative companies. [8] in Addition to these problems, there are also low employment and a modest contribution of SMEs to the development of the country's economy, as in emerging economies. [9], the need for entrepreneurial motivation. [10].

Quite a large number of modern economic research is devoted to specific issues of small and medium-sized businesses, including the problems of financing small businesses and entrepreneurs [11], the relationship between business development and the economy of territories on the example of agriculture [12], on the example of the petrochemical industry [13], [14],

Thus, there is no doubt that it is necessary to develop small and medium-sized businesses, provide financial and non-financial support and stimulate entrepreneurial and innovative activity.

\section{Methods}

The information and analytical base of the research is the normative legal acts regulating the system of strategic planning and development of the country's economy, official data provided by organizations of Executive authorities. The data of statistical reports of state organizations, research of domestic and foreign authors in the question were studied.

The study was conducted on the basis of in-depth analysis, data comparison, structural analysis, comparative analysis, grouping methods, correlation and regression analysis, and others.

\section{Results}

Activities in the innovative economy of small and medium-sized enterprises depend on the overall level of activity in the sectors of the economy of small and medium-sized enterprises, including the field of information technology, R\&d, etc. 
Table 1. Dynamics of trade turnover of medium-sized enterprises of the Russian Federation for the period 2017-2019, billion rubles.

\begin{tabular}{|l|l|l|l|}
\hline \multicolumn{1}{|c|}{ Type of economic activity } & \multicolumn{1}{c|}{$\mathbf{2 0 1 7}$} & \multicolumn{1}{c|}{$\mathbf{2 0 1 9}$} \\
\hline Agriculture, forestry & 402.3 & 439.5 & 402.4 \\
\hline Mining & 101.4 & 114.7 & 100.4 \\
\hline Manufacturing & 1594.7 & 1647.6 & 1599.5 \\
\hline The provision of electricity & 74.6 & 93.0 & 75.6 \\
\hline Water supply & 48.5 & 45.9 & 48.7 \\
\hline Construction & 500.3 & 512.4 & 514.1 \\
\hline Wholesale and retail trade & 2749.1 & 2907.9 & 2573.3 \\
\hline Transportation and storage & 261.2 & 237.5 & 222.7 \\
\hline Activities of hotels and catering establishments & 27.9 & 30.7 & 25.3 \\
\hline Activities in the field of information and communication & 100.9 & 106.6 & 103.6 \\
\hline Real estate operations & 143.7 & 148.6 & 143.1 \\
\hline Professional, scientific and technical activities, including & 161.2 & 210.8 & 183.3 \\
\hline Research and development & 47.3 & 52.4 & 48.6 \\
\hline Others & 122.5833 & 144.1844 & 154.7591 \\
\hline Source: data from the official website of the Federal state statistics service, updated on 24.04 .2020 & \\
\hline
\end{tabular}

Table 2. State support Tools for small and medium-sized businesses to expand access to funding sources in 2019.

\begin{tabular}{|c|c|c|c|c|}
\hline Country & Government guaranteed loans & Direct lending & Subsidized interest rates & SME banks \\
\hline Austria & + & + & + & + \\
\hline Belgium & + & + & - & - \\
\hline Canada & + & + & - & + \\
\hline Finland & + & + & + & + \\
\hline $\begin{array}{l}\text { Russian } \\
\text { Federation }\end{array}$ & + & + & + & + \\
\hline Turkey & + & + & + & + \\
\hline
\end{tabular}

The analysis of the volume of trade turnover of medium-sized enterprises by type of economic activity for the period 2017-2019 is presented in table 1.

It can be seen that the largest volumes of trade turnover are observed in the sphere of trade and manufacturing, followed by construction and agriculture. According to table 1, we can talk about the presence of medium-sized enterprises of the Russian Federation in such areas as: information and communication $(1.686 \%$ of the total turnover), as well as research and development $(0.791 \%$ of the total turnover), which characterizes professional, scientific and technical activities (2.98\% of the total turnover) in General, but this participation is quite low.

Innovative activity of small and medium-sized businesses in Russia directly depends on the variety of sources of financing for this type of company. According to the Federal state statistics service, the structure of sources of financing for small and medium-sized enterprises: own funds $-52.4 \%$, attracted funds- $47.6 \%$. At the same time, financial and credit institutions account for about $15 \%$. As for budget financing, it is no more than $7 \%$, while the share of budgets of the subjects of the Russian Federation accounts for a larger share and is $4.8 \%$, which confirms the "regional" nature of small and medium-sized businesses.

When studying the trend in the formation of sources of financing for small and medium-sized enterprises by the state in the context of countries, the following can be distinguished: loans, direct lending, interest rate subsidies, and the allocation of specialized banks to support SMEs are identified as support tools, which is reflected in table 2. [15]

Support for small and medium-sized businesses is reflected in National projects. For example, there is a national project "Small and medium-sized businesses", which includes 5 Federal projects: "Expanding the access of SMEs to financial resources, including concessional financing" in the budget of 261.8 billion rubles, "Acceleration of small and medium-sized businesses" from budgets of 167.9 billion rubles," Creating a system of support for farmers and 
Table 3. Tools for state support of startups (start-up) in order to expand access to funding sources in 2019.

\begin{tabular}{|l|l|l|l|}
\hline \multicolumn{1}{|c|}{ Country } & \multicolumn{1}{c|}{ Special guarantees and loans } & \multicolumn{1}{c|}{ Venture funds } & Co-investment of business angels \\
\hline Austria & + & + & + \\
\hline Belgium & + & + & + \\
\hline Canada & + & + & + \\
\hline Finland & + & + & + \\
\hline Russian Federation & - & + & + \\
\hline Turkey & + & + & + \\
\hline
\end{tabular}

development of rural cooperation " - 40.6 billion rubles," popularization of entrepreneurship " - 8.5 billion rubles," Improvement of business conditions " - 2.6 billion rubles.

The energy sector is supported by the state through the state program "energy Development". This program has been implemented since 2013 and is aimed at developing energy supply, improving energy efficiency, and developing the oil and gas and coal industries. The second stage of the program is already being implemented.

As a result of this program, the needs of the domestic market in providing electricity should be met, the efficiency of production of hydrocarbons, coal, and other measures aimed at innovative and digital development of the industry will increase. As a result of implementation, the growth rate of investment in fixed assets in the industry should reach $153.4 \%$ in 2024 compared to 2018 . In total, 157.7 billion rubles are provided for this direction, and about 103 billion rubles were used for the 1st stage. The distribution by year from 2013-2020 is shown in figure 1 , and by subprograms in figure 2 . It can be seen that most of the funds are spent on the development and modernization of the electric power industry $-36 \%$, and on the development of the coal industry-29\%. Besides



Fig. 1. the Amount of budget funds under the program "energy Development" in 2013-2020, billion rubles.

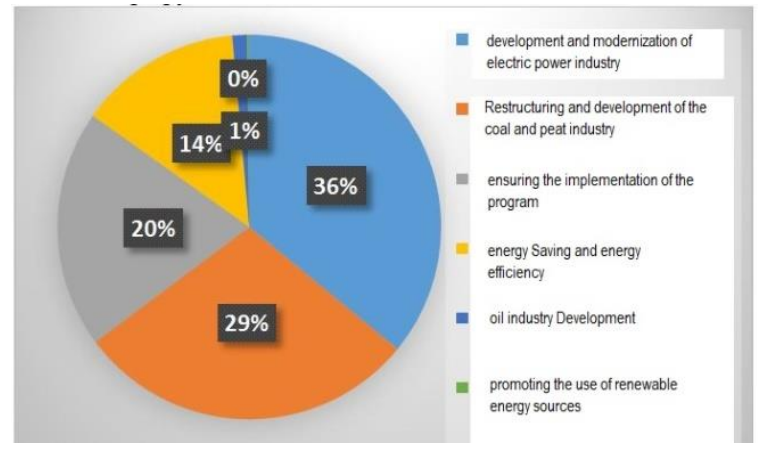

Fig. 2. Distribution of budget funds by subprograms of the energy Development program».

In August 2020, the rules for granting subsidies to reimburse part of the costs of implementing investment projects for the construction of liquefied natural gas refueling infrastructure - cryogenic gas refueling stations-were approved. A total of 80 stations are planned to be built. The subsidy rates depend on the capacity-from 45 to 62.5 million rubles. Expenses related to the acquisition and construction of such stations are reimbursed.

The state makes investments in the form of subsidies for capital investments in construction, reconstruction, design and survey work, technical re-equipment, and acquisition. Figure 3 shows the dynamics of public investment by type of work. It can be seen that

Most of the budget investment is directed to the construction of property objects.



Fig. 3. Public investment and provision of subsidies for capital investments.

According to the Report [15], a separate direction is allocated to startups, the sources of funding for which are shown in table 3 . 
Table 4. Structure of sources of financing of debt capital of SMEs in Austria for the period 2012-2018.

\begin{tabular}{|l|l|l|l|l|l|l|l|}
\hline \multicolumn{1}{|c|}{ Type, mln.rubbles } & \multicolumn{1}{|c|}{$\mathbf{2 0 1 2}$} & \multicolumn{1}{|c|}{$\mathbf{2 0 1 3}$} & \multicolumn{1}{|c|}{$\mathbf{2 0 1 4}$} & \multicolumn{1}{|c|}{$\mathbf{2 0 1 5}$} & \multicolumn{1}{c|}{$\mathbf{2 0 1 6}$} & \multicolumn{1}{c|}{$\mathbf{2 0 1 7}$} & \multicolumn{1}{c|}{$\mathbf{2 0 1 8}$} \\
\hline Loans (newly issued), including & 9347 & 8884 & 8237 & 8116 & 7499 & 8304 & 8182 \\
\hline short term & 4901 & 4536 & 4016 & 3345 & 3010 & 2539 & 1998 \\
\hline long-term & 4446 & 4348 & 4221 & 4771 & 4489 & 5755 & 6184 \\
\hline State loan guarantees & 158 & 167 & 172 & 204 & 192 & 279 & 301 \\
\hline Government credit & 207 & 211 & 225 & 258 & 282 & 456 & 441 \\
\hline Government direct lending & 539 & 594 & 490 & 543 & 454 & 649 & 545 \\
\hline
\end{tabular}

Table 5. Alternative sources of financing for SMEs in Austria.

\begin{tabular}{|l|l|l|l|l|l|l|l|}
\hline \multicolumn{1}{|c|}{ Type, million euros } & \multicolumn{1}{|c|}{$\mathbf{2 0 1 2}$} & \multicolumn{1}{|c|}{$\mathbf{2 0 1 3}$} & \multicolumn{1}{c|}{$\mathbf{2 0 1 4}$} & \multicolumn{1}{c|}{$\mathbf{2 0 1 5}$} & \multicolumn{1}{c|}{$\mathbf{2 0 1 6}$} & \multicolumn{1}{c|}{$\mathbf{2 0 1 7}$} & \multicolumn{1}{c|}{$\mathbf{2 0 1 8}$} \\
\hline Venture capital and capital growth & 73 & 86 & 105 & 197 & 85 & 287 & 123 \\
\hline Growth rate, $\%$ & $(66.31)$ & 17.76 & 22.56 & 87.97 & $(56.63)$ & 235.47 & $(56.94)$ \\
\hline
\end{tabular}

Table 6. Cost of borrowed sources of SME financing in Austria [15].

\begin{tabular}{|l|l|l|l|l|l|l|l|}
\hline \multicolumn{1}{|c|}{ Type, $\%$} & $\mathbf{2 0 1 2}$ & $\mathbf{2 0 1 3}$ & $\mathbf{2 0 1 4}$ & $\mathbf{2 0 1 5}$ & $\mathbf{2 0 1 6}$ & $\mathbf{2 0 1 7}$ & $\mathbf{2 0 1 8}$ \\
\hline $\begin{array}{l}\text { SME interest rate level, loan volume up to 1 } \\
\text { million euros }\end{array}$ & 2.46 & 2.28 & 2.27 & 2.02 & 1.92 & 1.8 & 1.82 \\
\hline $\begin{array}{l}\text { Interest rate level, loan volume over 1 million } \\
\text { euros }\end{array}$ & 1.98 & 1.77 & 1.74 & 1.61 & 1.54 & 1.45 & 1.38 \\
\hline Spread & 0.48 & 0.51 & 0.53 & 0.41 & 0.38 & 0.35 & 0.44 \\
\hline
\end{tabular}

Table 7. Structure of sources of financing of debt capital of SMEs of the Russian Federation for the period 2012-2018 [15].

\begin{tabular}{|l|l|l|l|l|l|l|l|}
\hline \multicolumn{1}{|c|}{ Type, billion rub. } & \multicolumn{1}{|c|}{$\mathbf{2 0 1 2}$} & \multicolumn{1}{|c|}{$\mathbf{2 0 1 3}$} & \multicolumn{1}{|c|}{$\mathbf{2 0 1 4}$} & \multicolumn{2}{c|}{$\mathbf{2 0 1 5}$} & \multicolumn{1}{c|}{$\mathbf{2 0 1 6}$} & \multicolumn{2}{c|}{$\mathbf{2 0 1 7}$} & \multicolumn{2}{c|}{$\mathbf{2 0 1 8}$} \\
\hline Loans (newly issued) & 6943 & 8065 & 7611 & 5460 & 5303 & 6117 & 6816 \\
\hline State loan guarantees & 28 & 30 & 22 & - & 102 & 141 & 146.4 \\
\hline State credit & 62 & 65 & 48 & - & 172 & 234 & 312 \\
\hline State direct credit & - & - & - & - & - & - & - \\
\hline
\end{tabular}

Let us consider as an example the structure of sources of financing of debt and equity of small and medium-sized enterprises in developed countries: Austria, Canada.

The structure of borrowed sources of financing for SMEs in Austria is shown in table 4.

According to table 4, it can be noted that the share of state support in the total amount of debt financing for SMEs is about $14 \%$ in 2018.

The cost of borrowed sources of Finance in Austria for SMEs is shown in table 6.

Let's look at the structure of borrowed sources of financing for SMEs in the Russian Federation, as shown in table 7. as you can see, most of them are loans.

Analysis of alternative sources of financing for SMEs in Russia allows us to conclude that the volume of venture capital is declining.

The cost of borrowed sources of financing in the Russian Federation in the activities of SMEs is presented in table 9.

According to table 9, the cost of debt financing of small and medium-sized enterprises in the Russian
Federation is higher than in developed countries, and varies in the range from 10.08 to $16.44 \%$ for the period 2014-2018.

In General, I would like to note that in modern market conditions, the activity of small and mediumsized enterprises in the field of knowledge and technology is quite high in developed countries. Thus, according to the report [16] in 2018, the share of SMEs engaged in product and process innovation in the total number of SMEs in Europe ranged from 12 to $48 \%$. The largest share was registered in Belgium (48\%), Ireland (46\%), Germany (42\%), Finland (44\%), the Netherlands (43\%), and Austria (41\%). It should be noted that the need to improve the competitiveness of SMEs was discussed in the 2005 UNCTAD report, where the activities of SMEs were considered as an integral part of the development of transnational corporations (TNCs). [17] 
Table 8. Alternative sources of financing for Russian SMEs.

\begin{tabular}{|l|l|l|l|l|l|l|l|}
\hline \multicolumn{1}{|c|}{ Type } & \multicolumn{1}{c|}{$\mathbf{2 0 1 2}$} & \multicolumn{1}{c|}{$\mathbf{2 0 1 3}$} & \multicolumn{1}{c|}{$\mathbf{2 0 1 4}$} & \multicolumn{1}{c|}{$\mathbf{2 0 1 5}$} & \multicolumn{1}{c|}{$\mathbf{2 0 1 6}$} & \multicolumn{1}{c|}{$\mathbf{2 0 1 7}$} & \multicolumn{1}{c|}{$\mathbf{2 0 1 8}$} \\
\hline $\begin{array}{l}\text { Venture capital and capital growth, } \\
\text { million USD }\end{array}$ & 24126 & 26251 & 25991 & 22386 & 19566 & 20398 & 22065 \\
\hline Growth rate, \% & 20.08 & 8.81 & $(0.99)$ & $(13.87)$ & $(12.6)$ & 4.25 & 8.17 \\
\hline Leasing, billion rubles & 2530 & 2900 & 3200 & 3100 & 3200 & 3450 & 4300 \\
\hline Factoring, billion rubles & 1230 & 1600 & 1650 & 1400 & 1530 & 1850 & 2630 \\
\hline
\end{tabular}

Table 9. the Cost of borrowed sources of financing for SMEs in the Russian Federation [15].

\begin{tabular}{|l|l|l|l|l|l|l|l|}
\hline \multicolumn{1}{|c|}{ Type, \% } & $\mathbf{2 0 1 2}$ & $\mathbf{2 0 1 3}$ & $\mathbf{2 0 1 4}$ & \multicolumn{1}{|c|}{$\mathbf{2 0 1 5}$} & \multicolumn{1}{|c|}{$\mathbf{2 0 1 6}$} & \multicolumn{1}{|c|}{$\mathbf{2 0 1 7}$} & \multicolumn{1}{c|}{$\mathbf{2 0 1 8}$} \\
\hline The interest rate for SMEs & - & - & 16.09 & 16.44 & 13.03 & 10.84 & 10.08 \\
\hline Interest rate level of large firms & - & - & 12.94 & 12.95 & 11.7 & 9.41 & 9.17 \\
\hline Spread & - & - & 3.15 & 3.49 & 1.33 & 1.43 & 0.91 \\
\hline
\end{tabular}

\section{Discussions}

Modern market conditions in which economic entities operate are constantly being transformed, complicated, and increasingly interdependent at all levels of the economic system, both at the macro, meso, and micro levels. At the same time, the latter are an integral element of the development of the national economy, including in the innovation sphere.

The correlation analysis revealed a direct high correlation (correlation coefficient $=0.87, \quad \mathrm{y}=0.033$ $\mathrm{x}+4053.2, \mathrm{R} 2=0.76$ ) between GDP and the number of SMEs, including microenterprises, which confirms the need to support increased growth in the number of SMEs. The correlation coefficient between GDP and turnover of medium-sized companies is 0.87 , and the constructed model shows a positive relationship between these indicators and describes $76 \%$ of cases.

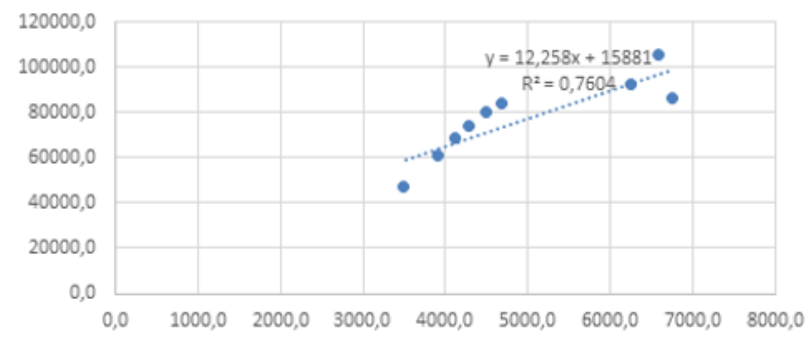

Fig. 4. Correlation and regression relationship between GDP and turnover of medium-sized enterprises in Russia, billion rubles.

Modern market conditions in which economic entities operate are constantly being transformed, complicated, and increasingly interdependent at all levels of the economic system, both at the macro, meso, and micro levels. At the same time, the latter are an integral element of the development of the national economy, including in the innovation sphere. At the same time, in order to increase the level of innovative development of small and medium-sized businesses, it is necessary to develop and implement a system of state support measures to form an "innovative layer" in the country's economy. The key advantages of SMEs are flexibility in making decisions on emerging external requests, which reduces both production costs and transaction costs. In developed countries, SMEs account for the largest share of the total number of enterprises. At the same time, practice shows that SMEs in General have limited access to financial resources on the territory of the Russian Federation, which limits their ability to build productive capacity. In this regard, the formation and development of a program to support small and medium-sized businesses will create the infrastructure that will be conditioned by the development of SMEs in the institutional economy.

Currently, a whole range of instruments for financing the activities of SMEs has been formed, such as state direct lending, interest rate subsidies, alternative forms of financing, in particular, venture financing, which contributes to the development of their potential in order to promote $\mathrm{R} \& \mathrm{~d}$, spread technologies, adapt existing technologies to changing conditions, and improve the qualification level of labor resources.

Summarizing the results of the study, we can say that it is necessary to support the activities of small and medium-sized enterprises to create an "innovation block" both in the regions and in the country as a whole. The preferred direction for creating cooperative relations can be identified in the field of $\mathrm{R} \& \mathrm{~d}$, which is due to the development of the institutional economy and the formation of vertical and horizontal cooperative relations both at the level of institutions and individual economic entities.

\section{References}

1. V.V. Karpov, A.A. Korableva, N.T. Mozzherina, Regional economy: theory and practice, 8 (383),3849 (2015) 
2. I. A. Bachurinskaya, Bulletin of the Altai Academy of Economics and law, 12(3), 5-12 (2019)

3. V.V. Mishchenko, A.Yu. Rezinkin, Business. Education. Right., 2 (47), 42-48 (2019)

4. N.A. Sadovnikova, E.N. Klochkova, Theory and practice of social development., 7, 93-97 (2014)

5. Maryam Imam Ibrahim, Bintu Mustafa. International Journal of Business and Economics Research, 8 (2), 41-49 (2019)

6. M. W. Staniewski, R. Nowacki, K. Awruk, International Entrepreneurship and Management Journal, 1-17. http://doi.org/10.1007/s11365-0160385-8 (2016).

7. A. Mottayeva, N. Gritsuk, MATEC Web of Conferences, 106, DOI: 10.1051 / matecconf/20171060 SPbWOSCE-2016 8083

8. V. Barinova, S. Zemtsov, Yu. Tsareva, Economy of Russia in 2018. Trends and prospects, 40, 543-563. (2019) available at SSRN: https://ssrn.com/abstract=3449232 http://dx.doi.org/10.2139/ssrn.3449232

9. O. V. Voronkova, A. A. Kurochkina, I. P. Firova, T. V. Bikezina, revista Apartments Espacios, 39, 13 (2018) available http://www.revistaespacios.com/a18v39n41/a18v39 n41p13.pdf

10. E. L. Eijdenberg, L. I. PAAs and masurel, E., journal of entrepreneurship in emerging economies, 7(3), 212- 240. (2015).

11. V. Botric and L. Bozic, EaM: managerial Economics, 20(1), 129-143. (2017).

12. Vladimir Kukuyev, journal Life Science journal. 11(6), 310-314

13. I. S. Tsertseil, V. V. Kookueva, Apartments Espacios, 38 (36), 247 (2017)

14. V. V. kukueva, Ya. s. Tsertseyil, European Research Studies Journal, 21(4), 818-830 (2018)

15. OECD report (2020), financing SMEs and entrepreneurs 2020: OECD scoreboard, OECD publishing house, Paris, URL: https://www.oecdilibrary.org

16. Report 2019. Annual report on European SMEs 2018/2019 research and development and innovation of SMEs background document.

17. Report. Improving the competitiveness of SMEs by strengthening their productive capacity. 2005. URL: https://unctad.org/en/Docs/iteteb20051_en.pdf. 